\title{
ANALISIS FAKTOR YANG MEMPENGARUHI NILAI PERUSAHAAN GO PUBLIC YANG MASUK DALAM INDEKS KOMPAS 100 DENGAN STRUKTUR MODAL SEBAGAI VARIABEL INTERVENING
}

\author{
Oleh \\ Astohar $^{1)}$, Dhian Andanarini Minar Savitri ${ }^{2)}$ \\ STIE Totalwin Semarang
}

\begin{abstract}
This research perfecting the research conducted by Hermuningsih (2013) and build structural factors that affect the value of customers who are affected by the growth opportunities and profitability either directly or through capital structure. The model is constructed by adding liquidity variable, measured by current ratio. The variables chosen to flesh out the previous model due to the current ratio of debate still going on against the capital structure or the value of the company. The increase of the $v$ liquidity variable expected able to fine-tune the structural model was built. Selected research objects are Kompas index 100 at Indonesia stock exchange in the period up to 2013 until 2017. Large samples are required for the research is as much as 100 companies that are consecutive - undertook to enter into Kompas Index 100 for five consecutive years - co-designer with sampling techniques using purposive non random sampling. Analysis tool used is the regression equation, i.e. first is the influence of liquidity, profitability and growth opportunities to the structure of capital. The second regression model is the influence of liquidity, growth opportunities, profitability and capital structure of the company. The research shows the Current ratio (CR) proved to have a negative and significant effect against the capital structure. Return on equity (ROE) proved to have a positive and significant effect against the value of the company. Asset growth opportunities are not proven to have a negative and significant effect against the capital structure. Current ratio (CR) proven asset growth opportunities have a positive and significant effect against the value of the company. Capital structure (debt to equity ratio) is not proven to mediate the effect of liquidity, profitability and growth opportunities of the company.
\end{abstract}

Keywords : likuiditas, growth, profitabilitas, struktur modal dan nilai perusahaan

\section{PENDAHULUAN}

Nilai pasar dari suatu ekuitas perusahaan ditambah nilai pasar hutang dapat diartikan Nilai perusahaan. Adanya penambahan jumlah ekuitas dari perusahaan tersebut dengan hutang perusahaan merupakan cerminan nilai perusahaan. Nilai perusahaan dapat menggambarkan keadaan perusahaan, meningkatnya nilai perusahaan maka perusahaan

Analisis Faktor Yang Mempengaruhi Nilai Perusahaan Go Public

Yang Masuk Dalam Indeks Kompas 100 Dengan Struktur Modal Sebagai Variabel Intervening

(Astohar, Dhian Andanarini Minar Savitri) 
akan dipandang baik oleh para calon investor, demikian pula sebaliknya nilai pemegang saham akan meningkat apabila nilai perusahaan meningkat yang ditandai dengan tingkat pengembalian investasi yang tinggi kepada pemegang saham.

Nilai perusahaan merupakan harga yang bersedia dibayar oleh calon pembeli (investor) apabila perusahaan tersebut dijual yang dikaitkan dengan harga saham (Kusumajaya, 2011, dalam Ayu dan Suarjaya, 2017). Nilai perusahaan dijadikan fokus utama dalam pengambilan keputusan oleh investor untuk berinvestasi pada sutau perusahaan atau tidak. Untuk dapat menarik minat investor, perusahaan mengharapkan manajer keuangan sehingga kemakmuran (kesejahteraan) pemegang saham dapat dicapai (Kosimpang, dkk, 2017). Nilai perusahaan merupakan persepsi investor terhadap perusahaan yang sering dikaitkan harga saham (Puspita, 2011, dalam Safitri). Semakin tinggi harga saham suatu perusahaan di pasar modal, maka menunjukkan semakin tingginya kekayaan pemilik perusahaan yang tercermin dari semakin tingginya nilai perusahaan. Nilai perusahaan yang tinggi menggambarkan bahwa kinerja perusahaan dalam keadaan baik sehingga dapat meyakinkan investor akan baiknya prospek perusahaan di masa mendatang (Ayu dan Suarjaya, 2017)

Nilai perusahaan yang diantaranya diukur melalui price book to value dipengaruhi oleh beberapa variable seperti growth opportunity (peluang pertumbuhan), profitabilitas dan struktur modal (leverage ratio) secara langsung (Hasania, dkk, 2016) yang diperkuat oleh Fadli, dkk (2013) dan Salempang dkk (2016). Pertumbuhan dan profitabilitas juga berpengaruh terhadap price book to value melalui struktur modal (leverage ratio). Model structural yang mempengaruhi nilai perusahaan melalui struktur modal dilakukan oleh Hermuningsih (2013) dan Safitri (2017).

Profitabilitas adalah tingkat keuntungan yang diperoleh oleh perusahaan pada saat menjalankan operasinya. Profitabilitas yang tinggi mencerminkan kemampuan perusahaan dalam menghasilkan keuntungan yang tinggi bagi pemegang saham. Tingkat profitabilitas yang tinggi akan diminati sahamnya oleh investor, sehingga permintaan saham meningkat dan harga saham akan naik (Aziz, 2016). Dampak dari profitabilitas terhdap struktur modal adalah berpengaruh yang positif (Safitri, 2017) serta berdampak pada nilai perusahaan (Yuliapratama dan Mardani, 2017). Sehingga kemampuan perusahaan dalam meningkatkan keuantungan akan berdampak pada penilaian positif dari masyarakat kepada perusahaan tersebut (Nofrita, 2013 dan Hermuningsih, 2013). 
Peluang pertumbuhan (Growth opportunity) adalah suatu kondisi dimana asset perusahaan terjadi peningkatan dari masa yang lalu ke masa depan (Mai, 2006). Menurut Indrajaya, dkk (2011) perusahaan yang memiliki tingkat pertumbuhan yang tinggi akan membutuhkan dana di masa depan yang lebih tinggi pula. Dampak dari peluang pertumbuhan terhadap struktur modal adalah mempunyai pengaruh yang positif (Yusrianti. 2013). Selain terhadap sturktur modal, peluang pertumbuhan juga mempunyai pengaruh positif terhadap nilai perusahaan (Budi dan Rachmawati, 2014). Menurut Pangulu dan Maski (2014) peningkatan kesempatan pertumbuhan dari perusahaaan akan berdampak pada peningkatan hutang oleh perusahaan atau dana eksternal.

Likuiditas merupakan kemampuan perusahaan untuk membayar kewajiban jangka pendek perusahaan. Likuiditas menjadi perhatian serius pada perusahaan karena likuiditas memainkan peranan penting dalam kesuksesan perusahaan (Owolabi, 2012, dalam Putra dan Lestari, 2016). Sedangkan menurut Mahendra (2012) likuiditas adalah kemampuan memenuhi kewajiban pendek yang harus segera dilakukan oleh perusahaan. Likuiditas perusahaan yang diukur dengan current ratio mempunyai pengaruh negative terhadap struktur modal perusahaan (Semakin likuid suatu perusahaan akan berdampak pada tingkat kepercayaan perusahaan untuk menurunkan struktur modalnya (Dewi dan Badjira. 2014). Selain berdampak pada struktur modal, likuiditas juga mempuyai dampak positif terhadap nilai perusahaan (Martikarini, 2012). Kemampuan perusahaan dalam memenuhi kewajiban jangka pendek mempunyai dampak pada penilaian masyarakat terhadap perusahaan berkaitan dengan nilai perusahaan (Hermuningsih, 2013).

Permasalahan dalam penelitian ini menggunakan pendekatan research gap yaitu dari penelitian ini dari agenda penelitian dari Hermuningsih (2013) yang memberikan rekomendasi model dalam penelitian ini hanya menggunakan variabel profitabilitas. growth opportunity dan nilai perusahaan. Lebih lanjut penelitian kedepan dengan memasukan variable likuiditas (current ratio) dalam mempengaruh struktur modal (Dewi Badjira, 2014). Selain itu likuiditas berpengaruh terhadap nilai perusahaan (Hartati, 2014). Hal ini didukung oleh penelitian dari Putra dan Lestari (2016) meningkatnya kemampuan dalam memenuhi kewajiban jangka pendek akan berdampak pada nilai perusahaan.

Analisis Faktor Yang Mempengaruhi Nilai Perusahaan Go Public

Yang Masuk Dalam Indeks Kompas 100 Dengan Struktur Modal Sebagai Variabel Intervening

(Astohar, Dhian Andanarini Minar Savitri) 
Variable likuiditas ini dijadikan sebagai penambahan variable adalah dari hasil agenda mendatang penelitian Hermuningsih (2013) masih ada gap yaitu likuiditas berpengaruh positif dan signifikan terhadap nilai perusahaan (Anslina dan Rustam, 2013). Perbedaan hasil menurut Jariah (2016) bahwa likuiditas berpengaruh negatif signifikan terhadap nilai perusahaan, sedangkan menurut Firnanda dan Oetomo (2016) bahwa likuiditas tidak terbukti berpengaruh terhadap nilai perusahaan. Kelemahan penelitian yang lain adalah perusahaan yang menjadi sampel dalam penelitian ini hanya perusahaan yang masuk dalam kategori LQ45 (Hermuningsih, 2013).

Agenda penelitian dari penelitian sebelumnya diharapkan sampelnya diperluas lagi. Berdasarkan pertimbangan tersebut obyek dari penelitian ini adalah mengambil obyek perusahaan yang masuk dalam Kompas 100 (Indeks Kompas 100). Pertimbangan yang dilakukan dalam pemilihan obyek pada sektor kompas 100 adalah nilai perusahaan yang lebih fluktuatif dibandingkan dibandingkan indeks LQ 45 dan Jakarta Islamic Indeks. Selain obyek berbeda. penelitian yang merupakan pengembangan dari Hermuningsih (2013) dengan menambah variable current ratio yang merupakan proksi dari rasio likuiditas.

Permasalahan yang dapat disajikan pada penelitian ini adalah adanya kelemahan penelitian dari Hermuningsih (2013), dimana pada model structural faktor - faktor yang mempengaruhi nilai perusahaan yang melalui struktur modal. Penelitian ini dengan menambahkan variabel current ratio (likuiditas) yang berpengaruh negative signifkan terhadap struktur modal (Badjira. 2014), sedangkan menurut Kristian dan Khuzaini (2014) yang menyatakan bahwa likuiditas mempunyai pengaruh yang positif terhadap struktur modal, sehingga terjadi gap.

Gap variable antara variable likuiditas terhadap nilai perusahaan juga terjadi antara Anggraeni (2015) diaman likuiditas berpengaruh positif signifikan terhadap nilai perusahaan, sedangkan Mahendra (2012) dan Hartanti (2014) yang menyatakan bahwa likuiditas tidak terbukti berpengaruh terhadap nilai perusahaan. Perbedaan juga terjadi pada penelitian Jariah (2016) yang memberikan hasil bahwa likuiditas berpengaruh negatif dan signifikan terhadap nilai perusahaan. 


\section{KAJIAN PUSTAKA DAN PENGEMBANGAN MODEL Pecking Order Theory (POT) dan Trade- Off Theory (TOT)}

Pecking Order Theory (POT)merupakan teori yang memprioritaskan sumbersumber pendanaan dari dalam terlebih dahulu. Pecking order theory mengasumsikan bahwa perusahaan bertujuan untuk memaksimumkan kesejahteraan pemegang saham. Teori ini dikenalkan pertama kali oleh Donaldson pada tahun 1961 sedangkan penamaan pecking order theory dilakukan oleh Myers (1984) dalam Nuswandari (2013). Menurut Wardani Dkk (2016) Pecking Order Theory (POT) menyatakan bahwa: (1) perusahaaan menyukai internal financing (pendanaan dari hasil opersai perusahaan berwujud laba ditahan) dan (2) apabila pendanaan dari luar (external financing) diperluakan, maka perusahaan akan menerbitkan sekuritas yang paling aman terlebih dahulu, yaitu dengan menerbitkan obligasi, kemudian diikuti oleh sekuritas yang berkarakteristik opsi (seperti, obligasi konversi), baru akhirnya apabila masih belum mencukupi, saham di terbitkan.

Trade Off Theory pertama kali diperkenalkan pada tahun 1963 oleh Modigliani dan Miller. Dalam teori ini menjelaskan ide bahwa berapa banyak utang perusahaan dan berapa banyak ekuitas perusahaan sehingga terjadinya keseimbangan antara biaya dan keuntungan. Trade off theory ini dikenal dengan nama balanced theory Husnan (2000) menganut pola keseimbangan antara keuntungan penggunaan dana dari utang dengan tingkat bunga yang tinggi dan biaya kebangkrutan. Teori keseimbangan (trade-off theory) merupakan penyeimbang manfaat dan pengorbanan yang timbul sebagai akibat penggunaan utang. Jika manfaat yang dihasilkan lebih besar, porsi utang dapat ditambah. Berdasarkan teori ini, perusahaan berusaha mempertahankan struktur modal yang ditargetkan dengan tujuan memaksimumkan nilai pasar. Teori ini menyatakan bahwa perusahaan menukar manfaat pajak dari pendanaan utang dengan masalah yang ditimbulkan oleh potensi kebangkrutan (Brigham dan Houston, 2011).

\section{Nilai Perusahaan}

Nilai perusahaan adalah persepsi dari investor pada perusahaan, yang sering dikaitkan harga saham (Puspita, 2011, dalam Safitri, 2017). Tingginya harga saham membuat nilai perusahaan juga tinggi. Harga saham merupakan harga yang terjadi pada saat saham diperdagangkan di pasar. Semakin tinggi harga saham, semakin tinggi pula nilai perusahaan. Nilai perusahaan yang tinggi menjadi keinginan para pemegang saham, sebab dengan nilai

Analisis Faktor Yang Mempengaruhi Nilai Perusahaan Go Public

Yang Masuk Dalam Indeks Kompas 100 Dengan Struktur Modal Sebagai Variabel Intervening

(Astohar, Dhian Andanarini Minar Savitri) 
yang tinggi, menunjukan kemakmuran pemegang saham juga tinggi (Ernawati, 2016). . Kekayaan pemegang saham dan perusahaan yang dipresentasikan oleh harga pasar dari saham yang merupakan cerminan dari keputusan investasi, pendanaan (financing) dan manajemen aset.). selanjutnya nilai perusahaan merupakan hasil kerja manajemen dari beberapa dimensi yaitu arus kas bersih, pertumbuhan dan biaya modal. Indikator dari nilai perusahaan adalah harga saham. Semakin tinggi harga saham, maka semakin tinggi nilai perusahaan (Herawati 2013).

Tingginya harga saham yang tinggi membuat nilai perusahaan juga semakin tinggi kepercayaan pasar adalah pada prospek perusahaan tersebut untuk masa - masa mendatang (Hermuningsih, 2013). Nilai perusahaan diciptakan oleh perusahaan melalui kegiatan perusahaan dari waktu ke waktu agar mencapai nilai perusahaan yang maksimum di atas nilai buku (Nofrita, 2013). Nilai perusahaan dalam penelitian ini diukur dengan price book value ratio (PBV) (Brigham dan Houston, 2011). Rasio price book value (PBV) memberikan gambaran tingkat kemampuan perusahaan menciptakan nilai relatif terhadap jumlah modal yang diinvestasikan. Peningkatan PBV mencerminkan harga saham yang tinggi dibandingkan nilai buku per lembar saham. Keberhasilan perusahaan dalam menciptakan nilai perusahaan tersebut tentunya memberikan harapan kepada pemegang saham berupa keuntungan yang lebih besar pula (Sartono, 2009).

\section{Likuiditas}

Likuiditas merupakan kemampuan perusahaan untuk memenuhi kewajiban jangka pendeknya.Semakin tinggi rasio maka semakin tinggi pula kemampuan perusahaan untuk memenuhi kewajibannya. Selain itu tingginya rasio likuiditas menggambarkan ketersediaan dana perusahaan untuk melakukan operasi perusahaan dan membayarkan dividen.Perusahaan yang memiliki tingkat likuiditas yang tinggi tentunya dianggap menjadi prospek yang bagus oleh para investor, karena para investor mempersepsikan perusahaan memiliki kinerja yang baik sehingga bisa meningkatkan harga saham yang berarti nilai perusahaan juga meningkat (Putra dan Lestari, 2016).

Menurut Horne dan Wachowicz (2013) rasio likuiditas berkaitan d kemampuan perusahaan dalam memenuhi kewajiban jangka pendek perusahaan. Beberapa pihak berkepentingan dalam menilai likuiditas perusahaan seperti kreditor dalam jangka pendek seperti pemasok dan bankir. Likuiditas tidak hanya berkenaan dengan keadaan dari 
keseluruhan keuangan perusahaan, tetapi juga berkenaan dengan kemampuannya untuk mengubah aktiva lancar tertentu menjadi uang kas (Syamsuddin, 2011).

Proksi dari rasio likuditas adalah current ratio yaitu rasio yang menujukkan kemampuan dalam jangka pendeknya. Tingginya tingkat likuiditas perusahaan menyebabkan perusahaan tersebut memiliki dana internal yang lebih besar, ini berarti perusahaan lebih memilih dana internalnya digunakan terlebih dahulu dalam membiayai investasi. Hasil penelitian oleh Mikrawardhana (2015), dan Wardani (2015) menyatakan bahwasanya likuiditas memiliki dampak negatif terhadap struktur modal. Berdasarkan hasil itu dapat diberika gambaran bahwa peningkatan likuiditas justru berdampak pada penurunan struktur modal. Berdasarkan pernyataan tersebut dapat diajukan hipotesis pertama $\left(\mathrm{H}_{1}\right)$ sebagai berikut :

$\mathrm{H}_{1}$ : Variabel likuiditas mempunyai pengaruh yang negative dan signifikan terhadap struktur modal

Lebih lanjut dapat dikembangkan bahwa adanya peningkatan current ratio (CR) menunjukkan semakin likuid sebuah perusahaan tersebut (Mahendra, 2012). Dalam penelitiannya mengungkapkan bahwa likuiditas berpengaruh positif terhadap nilai perusahaan. Hasil serupa diungkapkan Prisilia (2013) yang mengungkapkan bahwa likuiditas berpengaruh terhadap nilai perusahaan. Makin tinggi likuiditas perusahaan, dana yang tersedia dalam jangka pendek juga mengalami peningkatan yang digunakan untuk membiayai operasionalnya. Hasil penelitian dari Mahendra (2012) bahwa likuiditas terbukti mempunyai pengaruh yang positif dan signifikan terhadap nilai perusahaan. Hal ini menunjukkan kemampuan dalam memenuhi kewajiban dalam jangka pendek akan meingkatkan nilai perusahaan (Putra dan Lestari, 2016). Dampaknya pada persepsi investor pada kinerja pada perusahaan tersebut (Anggraini, 2015). Berdasarkan hasil penelitian diatas dapat diajukan hipotesis keempat $\left(\mathrm{H}_{4}\right)$ yaitu sebagai berikut :

$\mathrm{H}_{4}$ : Variabel likuiditas mempunyai pengaruh yang positif dan signifikan terhadap nilai perusahaan

Analisis Faktor Yang Mempengaruhi Nilai Perusahaan Go Public

Yang Masuk Dalam Indeks Kompas 100 Dengan Struktur Modal Sebagai Variabel Intervening

(Astohar, Dhian Andanarini Minar Savitri) 


\section{Peluang Pertumbuhan}

Perusahaan yang mengalami pertumbuhan tinggi di masa mendatang cenderung menggunakan saham untuk pendanaan operasional perusahaan, demikian sebaliknya (Mai, 2006). Laba ditahan dari perusahaan - perusahaan dengan tingkat pertumbuhan yang tinggi akan meningkat, dan perusahaan - perusahaan tersebut akan lebih banyak melakukan utang untuk mempertahankan rasio utang yang ditargetkan. Laba dari perusahaan akan lebih banyak ditahan oleh perusahaan untuk mempertahankan tingkat pertumbuhan yang tinggi (Hermuningsih, 2013).

Peluang pertumbuhan (growth opportunity) merupakan perubahan dari total aktiva dari suatu perusahaan (Kartini dan Arianto, 2008). Peluang pertumbuhan adalah suatu pertumbuhan aktiva perusahaan di masa depan (Mai, 2006, dalam Hermuningsih, 2013). Besaran ini mengukur sejauh mana laba per lembar saham suatu perusahaan dapat ditingkatkan oleh leverage. Perusahaan-perusahaan yang memiliki pertumbuhan yang cepat seringkali harus meningkatkan aktiva tetapnya.

Laba ditahan dari perusahaan-perusahaan dengan tingkat pertumbuhan yang tinggi akan meningkat. Perusahaan yang mengalami pertumbuhan akan menutup pertumbuhan tersebut dengan mengambil pinjaman (utang). Hal ini dimaksudkan untuk mempertahankan rasio struktur modal dari yang ditargetkan (Hermuningsih, 2013). Perusahaan yang memiliki pertumbuhan yang cepat membutuhkan pendanaan lebih besar di masa depan sehingga harus meningkatkan aktiva tetapnya dan lebih banyak mempertahankan laba. Menurut Yusriyanti (2013) secara empiris growth opportunity berpengaruh positif terhadap sruktur modal. Hal ini didukung oleh Hermuningsih (2013) bahwa peningkatan pertumbuhan membawa dampak pada nilai perusahaan. Berdasarkan argument tersebut dapat diajukan hipotesis kedua $\left(\mathrm{H}_{2}\right)$ adalah sebagai berikut :

$\mathrm{H}_{2}$ : Peluang pertumbuhan berpengaruh positif dan signifikan terhadap struktur modal

Pertumbuhan asset dihitung sebagai persentase perubahan aset pada saat tertentu terhadap tahun sebelumnya. Potensi pertumbuhan mempunyai pengaruh positif dan signifikan terhadap nilai perusahaan (Hermuningsih, 2013). Pertumbuhan dinyatakan sebagai pertumbuhan total aset di mana pertumbuhan aset masa lalu akan menggambarkan profitabilitas yang akan datang dan pertumbuhan yang akan datang (Kusumajaya, 2011). Lebih lanjut menurut Budi dan Rachmawati (2014) yang dimana 
peningkatan potensi pertumbuhan berdampak pada nilai perusahaan. Berdasarkan penelitian tersebut dapat diajukan hipotesis kelima $\left(\mathrm{H}_{5}\right)$ adalah sebagai berikut :

$\mathrm{H}_{5}$ : Peluang pertumbuhan berpengaruh positif dan signifikan terhadap nilai perusahaan

\section{Profitabilitas}

Profitabilitas merupakan kemampuan suatu perusahaan untuk mendapatkan laba (keuntungan) dalam suatu periode tertentu (Ernawati, 2016). Rasio profitabilitas mengukur kemampuan perusahaan dalam menghasilkan keuntungan dari kegiatan bisnis yang dilakukan. Hasilnya investor dapat melihat seberapa efisien perusahaan menggunakan asset dan dalam melakukan operasinya untuk menghasilkan keuntungan. Rasio profitabilitas merupakan hasil akhir dari sejumlah kebijakan dan keputusan yang dilakukan oleh perusahaan (Mardiyati Dkk, 2012). Profitabilitas adalah kemampuan perusahaan memperoleh laba dalam hubungannya dengan penjualan, total aktiva, maupun modal sendiri (Wulandari. 2010).

Profitabilitas perusahaan merupakan salah satu cara untuk menilai secara tepat sejauh mana tingkat pengembalian yang akan didapat dari aktivitas investasi. Jika kondisi perusahaan dikategorikan menguntungkan atau menjanjikan keuntungan dimasa mendatang maka banyak investor yang akan menanamkan dananya untuk membeli saham perusahaan tersebut (Puspita, 2011, dalam Safitri, 2017). Peningkatan profitabilitas menunjukkan adanya prospek perusahaan dari perusahaan tersebut, sehingga investor akan merespon sebagai sinyal positif dan nilai perusahaan akan meningkat (Sujoko dan Soebiantoro, 2007, dalam Apsari dkk, 2015).

Perusahaan yang memiliki tingkat keuntungan lebih tinggi akan menggunakan utang yang relatif lebih kecil dibandingkan perusahaan dengan keuntungan yang rendah. Tingkat keuntungan yang tinggi memungkinkan mereka untuk memperoleh sebagian besar pendanaan dari laba ditahan (Amalia dan Alfianto, 2014). Perusahaan akan cenderung memilih laba ditahan untuk membiayai sebagian besar kebutuhan pendanaan. Profitabilitas menjadi dasar penilaian kondisi keuangan dalam menghasilkan laba suatu perusahaan (Apsari dkk, 2015).

Penelitian dari Yusrianti (2013) memberikan hasil bahwa ada pengaruh yang negative dan signifikan antara profitabilitas terhadap struktur modal. Hal ini diperkuat dari penelitian Hermuningsih (2013) dan Resino dkk (2015) yaitu meningkatkan profitabilitas akan menurunkan penggunaan rasio hutang. Sehingga dapat diberikan

Analisis Faktor Yang Mempengaruhi Nilai Perusahaan Go Public

Yang Masuk Dalam Indeks Kompas 100 Dengan Struktur Modal Sebagai Variabel Intervening

(Astohar, Dhian Andanarini Minar Savitri) 
gambaran bahwa kemampuan perusahaan dalam menghasilkan laba dari aktiva tetap ataupun modal sendiri akan berdampak pada penurunan hutang perusahaan (Safitri, 2017). Berdasarkan argumen tersebut dapat diajukan hipotesis ketiga $\left(\mathrm{H}_{3}\right)$ yaitu sebagai berikut :

$\mathrm{H}_{3}$ : Profitabilitas berpengaruh negative dan signifikan terhadap struktur modal

Menurut Nofrita (2013) adanya peningkatan kemampuan perusahaan dalam menghasilkan laba akan berdampak pada peningkatan harga saham. Peningkatan harga saham merupakan cerminan nilai perusahaan yang baik bagi investor. Peningkatan nilai pemegang saham dengan nilai perusahaan meningkat yang ditandai dengan tingkat pengembalian investasi yang tinggi kepada pemegang saham. Tingkat pengembalian investasi kepada pemegang saham tergantung pada laba yang dihasilkan perusahaan. (Hermuningsih, 2013). Hasil penelitian Astohar (2017) menunjukkan bahwa ada pengaruh yang positif dan signifikan antara profitabilitas terhadap nilai perusahaan. Hal ini diperkuat oleh Safitri (2013) serta Yuliapratama dan Mardani (2017) meningkatkan rasio profitabilitas akan meningkatkan nilai perusahaan. Berdasarkan hasil penelitian tersebut diajukan hipotesis keenam $\left(\mathrm{H}_{6}\right)$ sbb:

$\mathrm{H}_{6}$ : Profitabilitas berpengaruh positif dan signifikan terhadap nilai perusahaan

\section{Struktur Modal}

Dalam melakukan operasional ada 2 piliihan penggunaan dana, yaitu dana dari dalam atau modal sendiri atau menggunakan pinjaman (dana dari luar). Risiko yang ditanggung juga mempunyai tingkat yang bermacam - macam (Kosimpang, dkk, 2017). Struktur modal merupakan perbandingan antara modal eksternal (pinjaman) dengan modal sendiri. Aspek yang penting bagi setiap perusahaan karena mempunyai efek secara langsung terhadap komposisi finansial dari perusahaan. Perusahaan yang memiliki aktiva berwujud cukup besar akan mempunyai kecenderungan menggunakan hutang dalam proporsi yang lebih besar pula (Hermuningsih, 2012). Struktur keuangan mencerminkan perimbangan baik dalam artian absolut maupun relatif antara keseluruhan modal asing dengan jumlah modal sendiri (Riyanto, 2010).

Struktur modal merupakan kombinasi utang dan ekuitas dalam struktur keuangan jangka panjang perusahaan, tidak seperti rasio utang yang hanya menggambarkan target komposisi utang dan ekuitas dalam jangka panjang pada suatu perusahaan (Arifin, 2005 dalam Yusrianto, 2013). Kebijakan hutang yang diukur dengan debt to equity ratio (DER) 
berpengaruh positif dan signifikan terhadap price book value (Hermuningsih, 2013). Hasil ini diperkuat oleh penelitian dari Hamidy (2015) dan Astohar (2017) ada pengaruh yang signifkan antara struktur modal terhadap nilai perusahaan. Berdasarkan hasil penelitian tersebut diajukan hipotesis keenam $\left(\mathrm{H}_{7}\right)$ yaitu sebagai berikut :

$\mathrm{H}_{7}$ : Struktur modal berpengaruh positif dan signifikan terhadap nilai perusahaan

\section{METODE PENELITIAN}

\section{Definisi Konsep dan Operasional Variabel}

Tabel 1 : Definisi Konsep dan Operasional Variabel

\begin{tabular}{|c|c|c|c|}
\hline $\begin{array}{l}\text { Variabel } \\
\text { Bebas }\end{array}$ & proksi & Definisi operasional & Rumus \\
\hline likuiditas & $\begin{array}{l}\text { Current } \\
\text { ratio }\end{array}$ & $\begin{array}{l}\text { Kemampuan perusahaan } \\
\text { dalam memenuhi } \\
\text { kewajiban jangka pendek }\end{array}$ & $\mathrm{CR}=\frac{\text { Aktiva lancar }}{\text { Hutang lancar }}$ \\
\hline $\begin{array}{l}\text { Peluang } \\
\text { Pertumbuhan }\end{array}$ & $\begin{array}{l}\text { Aset } \\
\text { Growth }\end{array}$ & $\begin{array}{l}\text { Peluang pertumbuhan } \\
\text { suatu perusahaan di masa } \\
\text { depan }\end{array}$ & $\mathrm{AG}=\frac{\text { Aset } t-\text { asset } t-1}{\text { Asset } t-1}$ \\
\hline Profitabilitas & ROE & $\begin{array}{l}\text { Hubungan antara tingkat } \\
\text { keuntungan yang } \\
\text { dihasilkan manajemen } \\
\text { atas modal sendiri }\end{array}$ & $\mathrm{ROE}=\frac{\text { Laba setelah } p j k}{\text { Modal sendiri }}$ \\
\hline $\begin{array}{l}\text { Struktur } \\
\text { Modal } \\
\text { (Intervening) }\end{array}$ & DER & $\begin{array}{l}\text { Hubungan antara total } \\
\text { hutang terhadap modal } \\
\text { sendiri }\end{array}$ & $\mathrm{DER}=\frac{\text { Total Hutang }}{\text { Modal Sendiri }}$ \\
\hline $\begin{array}{l}\text { Nilai } \\
\text { Perusahaan } \\
\text { (variable } \\
\text { terikat) }\end{array}$ & PBV & \begin{tabular}{lr} 
Persepsi & investor \\
terhadap & tingkat \\
keberhasilan perusahaan \\
dalam mengelola sumber \\
\multicolumn{2}{c}{ daya pada tahun berjalan } \\
\end{tabular} & $\mathrm{PBV}=\frac{\text { Harga Pasar Per lbr shm }}{\text { Nilat Buku per Lbr shm }}$ \\
\hline
\end{tabular}

Populasi dalam penelitian ini adalah seluruh perusahaan yang masuk dalam indeks kompas 100 pada tahun 2013 - 2017. Pemilihan sampel dilakukan dengan menggunakan metode purposive sampling dan menghasilkan sampel 100 perusahaan yang masuk indeks kompas 100. Perusahaan yang tidak secara terus menerus masuk ke Indeks kompas dan tidak lengkap serta tidak memenuhi syarat ada 24 perusahaan atau 120 observasi. Sebanyak 380 observasi yang diolah masih terjadi data atau observasi yang outlier yaitu 40 observasi. Berdasarkan tahapan ini data yang dapat digunakan adalah 340 observasi

Analisis Faktor Yang Mempengaruhi Nilai Perusahaan Go Public

Yang Masuk Dalam Indeks Kompas 100 Dengan Struktur Modal Sebagai Variabel Intervening

(Astohar, Dhian Andanarini Minar Savitri) 


\section{Jenis dan Metode Pengumpulan Data}

Penelitian ini menggunakan data kuantitatif berupa laporan keuangan publikasi tahunan yang diterbitkan oleh Indonesia Capital Market Directory (ICMD) dari periode tahun 2013 sampai tahun 2017. Sumber data yang digunakan ini diperoleh melalui penelusuran dari media internet dari www. idx.go.id dan website resmi PT. Bursa Efek Indonesia. Metode pengumpulan data yang digunakan yaitu melalui studi pustaka dari direktori perusahaan go publik dan situs resmi tiap perusahaan. idx.go.id. serta situs situr resmi lainnya yang dijadikan sampel.

\section{Alat Analisis Data \\ Uji Persamaan Regresi Ganda}

Analisis regresi linier berganda adalah pengaruh secara linier antara dua atau lebih variabel independen dengan satu variabel dependen yang digunakan untuk memprediksi atau meramalkan suatu nilai variabel dependen berdasarkan variabel independen. Sebelum melakukan estimasi yang tidak biasa dengan analisis regresi, perlu dilakukan uji $\mathrm{t}$ dan uji Fit data yaitu pengujian antar variabel bebas supaya tidak terjadi multikolinieritas, heteroskedastisitas, normalitas, dan autokorelasi

Persamaan regresi pada penelitian ini terdapat dua model. yaitu sebagai berikut :

$I=\beta_{0}+\beta_{1} X_{1}+\beta_{2} X_{2}+\beta_{3} X_{3}+e$

$Y=\beta_{0}+\beta_{1} X_{1}+\beta_{2} X_{2}+\beta_{3} X_{3}+\beta_{4} I+e$

I : struktur modal

$\mathrm{X}_{1} \quad$ : likuiditas

$\mathrm{X}_{2}$ : peluang pertumbuhan

$\mathrm{X}_{3}$ : profitabilitas

$\mathrm{Y}$ : nilai perusahaan

\section{Koefisien Determinasi}

Koefisien determinasi pada intinya untuk mengukur seberapa jauh kemampuan model dalam menerangkan variasi variabel dependen. Koefisien determinan pada penelitian ini digunakan untuk melihat berapa persen dari variasi variabel terikat dijelaskan variabel bebas. (Ghozali, 2013).

\section{Sobel Test}

Variabel intervening adalah variabel yang ikut mempengaruhi pengaruh antara variabel prediktor (independen) dan variabel criterion (dependen) Baron dan Kenny (1986) dalam Ghozali (2013). Pengujian hipotesis mediasi dapat dilakukan dengan 
prosedur yang dikembangkan oleh Sobel (1982) dan dikenal dengan Uji Sobel (Sobel Test).

\section{HASIL DAN PEMBAHASAN}

\section{Analisis Deskriptif}

Rata - rata current ratio yang rata-ratanya adalah sebesar 2,11. Berdasarkan rata rata, perusahaan go public yang masuk indeks kompas 100 masuk dalam kategori yang likuid (1 sd 2). Berdasarkan data yang diperoleh current ratio (CR) terendah selama periode penelitian adalah sebesar 0,23 yaitu PT. Hanson International, Tbk pada tahun 2017 dan yang tertinggi adalah sebesar 12,99 pada PT. Baturaja (Persero), Tbk pada tahun 2016.

Peluang pertumbuhan asset ini menunjukkan bahwa berdasarkan rata - rata perusahaan masuk dalam kategori yang pertumbuhan cukup baik, hal ini ditandai dengan rata - rata peluang pertumbuhan asset pada kisaran 0,19\% (cukup baik). Peluang pertumbuhan asset terendah selama periode penelitian adalah sebesar - 0,89 pada PT. Tambang Batubara Bukit Asam, Tbk pada tahun 2013 dan tertinggi adalah sebesar 9,50 pada PT. Tambang Bukit Asam, Tbk pada tahun 2014. Hal ini menunjukkan ada penambahan asset yang signifikan yang disebabkan ekspansi dari perusahaan tersebut.

Return on equity ( $R O E$ ) ini menunjukkan bahwa berdasarkan rata - rata perusahaan adalah sebesar 10,66 \% atau masuk dalam kategori yang bagus, hal ini ditandai dengan rata - rata return on equity (ROE) dikisaran diatas $10 \%$. Return on equity (ROE) terendah selama periode penelitian adalah sebesar - 34,26 pada PT. Delta Dunia Makmur, Tbk pada tahun 2017 dan tertinggi adalah sebesar 50,54 \% pada PT. Tower Bersama Infrastructure, Tbk tahun 2014.

Debt to equity ratio (DER) ini menunjukkan bahwa berdasarkan rata - rata perusahaan masuk dalam kategori yang kurang bagus, hal ini ditandai dengan rata - rata debt to equity ratio (DER) dikisaran diatas $50 \%$ yaitu sebesar $1,31 \mathrm{x}$ atau $131 \%$. debt to equity ratio $(D E R)$ terendah selama periode penelitian adalah sebesar -0,02 pada PT.

Analisis Faktor Yang Mempengaruhi Nilai Perusahaan Go Public

Yang Masuk Dalam Indeks Kompas 100 Dengan Struktur Modal Sebagai Variabel Intervening

(Astohar, Dhian Andanarini Minar Savitri) 
Gajah Tunggal, Tbk pada tahun 2015 dan tertinggi adalah sebesar 16,21 pada PT. Delta Makmur, Tbk pada tahun 2017.

Price to book value $(P B V)$ ini menunjukkan bahwa berdasarkan rata - rata perusahaan masuk dalam kategori yang sehat atau bagus, hal ini ditandai dengan rata rata price to book value $(P B V)$ masih dikisaran 1,98 (sehat lebih dari 1,5). Price to book value $(P B V)$ terendah selama periode penelitian adalah sebesar 0,05 pada PT. Indika Energy, Tbk tahun 2015 dan tertinggi adalah sebesar 9,14 pada PT. Tower Bersama Infrastruktur, Tbk pada tahun 2014.

\section{Uji Penyimpangan Asumsi Klasik}

Langkah screening data merekomendasikan untuk membuang data sebanyak 40 observasi. Setelah 40 data dikeluarkan model terdisitribusi secara normal, yang ditandai dengan grafik normal P - P Plot Regression yang titik-titik pada grafik menyebar disekitar garis diagonal, serta penyebarannya mengikuti arah garis diagonal. Selain itu pada grafik Histogram yang menunjukkan sebaran data mendekati garis normal.

Model terbebas dari penyimpangan Multikolinearitas, yaitu dibuktikan dengan nilai tolerance diatas 0,1 yaitu masing - masing sebesar 0,$940 ; 0,996 ; 0,977$ dan 0,957 dan nilai variance inflation factor (VIF) dibawah 10 yaitu masing - masing 1,064;1,004 ; 1,024 dan 1,045. Selain itu nilai koefisien korelasi antar variabel bebas adalah lemah yaitu sebesar 0,$018 ; 0,021 ; 0,202 ;-0,056 ;-0,006$ dan 0,133 yang mana nilai tersebut masih dibawah 0,7 .

Model terbebas dari penyimpangan heteroskedastisitas yang ditandai grafik sccaterplot (lampiran) tidak membentuk pola khusus atau gambarnya menyebar. serta terbebas dari penyimpangan autokorelasi, yaitu ditandai dengan nilai durbin Watson sebesar 1,115 yang mana nilai tersebut masuk dalam areal tanpa kesimpulan.

\section{Uji Simultan (Uji Fit Data)}

Hasil uji fit data diperoleh nilai $\mathrm{F}$ hitung sebesar 25,144 serta nilai probabilitas sebesar 0,000. Hasil perbandingan menunjukkan bahwa nilai probabilitas $(0,000)<\alpha$ $(0,05)$ dan $F$ hitung lebih besar dari F tabel $(25,144>2,45)$. Sehingga dapat dikatakan bahwa permodelan yang dibangun memenuhi kriteria fit.

\section{Analisis Regresi}

Persamaan regresi berganda yang pertama sebagai berikut :

DER $=1,763-0,193 \mathrm{CR}-0,046 \mathrm{Grwt}-0,003 \mathrm{ROE}$ 
Hasil konstanta diperoleh nilai 1,763 yang dapat diartikan bahwa tanpa adanya perubahan dari variabel bebas atau variabel current ratio (CR), peluang pertumbuhan asset dan return on equity (ROE) maka struktur modal (debt to equity ratio) pada perusahaan mengalami peningkatan.

Current ratio (CR) perusahaan yang masuk dalam indeks kompas 100 di Bura Efek Indonesia mempunyai pengaruh negatif terhadap struktur modal (debt to equity ratio) dengan koefisien regresi sebesar - 0,193. Hasil pengujian menunjukkan bahwa hipotesis 1 $\left(\mathrm{H}_{1}\right)$ terbukti signifikan, hal ini dapat ditunjukkan dengan nilai t hitung sebesar - 3,772 yang kurang dari t tabel $(-1,96)$ serta nilai probabilitas $(0,000)<\alpha(0,05)$. Hasil penelitian ini sejalan dengan penelitian yang telah dilakukan Hardanti dan Gunawan (2010, yakni ada pengaruh yang negative dan signifikan antara likuiditas terhadap struktur modal perusahaan. Lebih lanjut menurut Dewi dan Badjira (2014) yang diperkuat oleh Wardani (2015) bahwa meningkatnya current ratio justru banyak dana yang menganggur, akibatnya struktur modal semakin menurun.

Peluang pertumbuhan asset perusahaan yang masuk dalam indeks kompas $100 \mathrm{di}$ Bura Efek Indonesia mempunyai pengaruh negatif terhadap struktur modal (debt to equity ratio) dengan koefisien regresi sebesar - 0,046. Hasil pengujian menunjukkan bahwa hipotesis $2\left(\mathrm{H}_{2}\right)$ tidak terbukti signifikan, hal ini dapat ditunjukkan dengan nilai t hitung sebesar - 0,326 yang lebih dari t tabel $(-1,96)$ serta nilai probabilitas $(0,745)>\alpha(0,05)$. Hasil penelitian ini berbeda dengan penelitian yang dilakukan oleh Hermuningsih (2013) dan Yusrianti (2013), dimana pertumbuhan aset berpengaruh positif dan signifikan terhadap struktur modal. Penelitian ini sejalan dengan Dewi dan Sudhiarta (2016) bahw pertumbuhan Aset berpengaruh negatif tidak signifikan terhadap nilai perusahaan. Pertumbuhan aset yang semakin meningkat justru akan menurunkan struktur modal, artinya asset yang makin meningkat dapat menurut debt to equity ratio.

Return on equity (ROE) perusahaan yang masuk dalam indeks kompas 100 di Bura Efek Indonesia mempunyai pengaruh negatif terhadap struktur modal (debt to equity ratio) dengan koefisien regresi sebesar - 0,003. Hasil pengujian menunjukkan bahwa hipotesis $3\left(\mathrm{H}_{3}\right)$ tidak terbukti signifikan, hal ini dapat ditunjukkan dengan nilai t hitung sebesar - 0,390 yang lebih dari $\mathrm{t}$ tabel $(-1,96)$ serta nilai probabilitas $(0,696)>\alpha(0,05)$.

Analisis Faktor Yang Mempengaruhi Nilai Perusahaan Go Public

Yang Masuk Dalam Indeks Kompas 100 Dengan Struktur Modal Sebagai Variabel Intervening

(Astohar, Dhian Andanarini Minar Savitri) 
Hasil penelitian ini berbeda dengan penelitian yang dilakukan oleh Hermuningsih (2013) dan Resino (2015), dimana profitabilitas (return on equity) berpengaruh negatif dan signifikan terhadap struktur modal. Penelitian ini sejalan dengan Kosimpang, dkk (2017) bahwa profitabilitas (return on equity) berpengaruh negatif tidak signifikan terhadap struktur modal. Peningkatan profitabilitas tidak secara langsung berdampak pada penurunan struktur modal.

Persamaan regresi berganda yang kedua sebagai berikut :

$\mathrm{PBV}=1,086+0,026 \mathrm{CR}+0,011 \mathrm{GRWT}+0,064 \mathrm{ROE}+0,124 \mathrm{DER}$

Nilai konstanta pada penelitian ini diperoleh nilai 1,086 yang dapat diartikan bahwa tanpa adanya perubahan dari variabel bebas atau variabel cuurent ratio $(\mathrm{CR})$, peluang pertumbuhan asset, return on equity dan debt to equity ratio maka nilai perusahaan (price to book value) pada perusahaan mengalami peningkatan.

Current ratio (CR) perusahaan yang masuk dalam indeks kompas 100 di Bura Efek Indonesia mempunyai pengaruh negatif terhadap nilai perusahaan (price to book value) dengan koefisien regresi sebesar 0,026. Hasil pengujian menunjukkan bahwa hipotesis 4 $\left(\mathrm{H}_{4}\right)$ terbukti signifikan, hal ini dapat ditunjukkan dengan nilai t hitung sebesar 0,617 yang kurang dari t tabel $(1,96)$ serta nilai probabilitas $(0,538)>\alpha(0,05)$. Hasil penelitian ini berbeda dengan penelitian yang dilakukan oleh Nugroho (2012) dimana likuiditas (current ratio) berpengaruh positif dan signifikan terhadap nilai perusahaan. Penelitian ini sejalan dengan Mahendra (2012) dan Aditya (2015) bahwa likuiditas (current ratio) berpengaruh positif tidak signifikan terhadap nilai perusahaan. Peningkatan likuiditas tidak secara langsung berdampak pada peningkatan nilai perusahaan. Peningkatan likuiditas dapat juga berdampak perusahaan kurang efisien dalam memanfaatkan modal kerjanya, sehingga nilai perusahaan tidak secara langsung meningkat.

Peluang pertumbuhan asset perusahaan yang masuk dalam indeks kompas 100 di Bura Efek Indonesia mempunyai pengaruh positif terhadap nilai perusahaan dengan koefisien regresi sebesar 0,098. Hasil pengujian menunjukkan bahwa hipotesis $5\left(\mathrm{H}_{5}\right)$ tidak terbukti signifikan, hal ini dapat ditunjukkan dengan nilai t hitung sebesar 0,098 yang kurang dari t tabel $(1,96)$ serta nilai probabilitas $(0,922)>\alpha(0,05)$. Hasil penelitian ini berbeda dengan penelitian yang dilakukan oleh Hermuningsih (2013) serta oleh Budi dan Rahmawati (2014) dimana peluang pertumbuhan (growth) berpengaruh positif dan signifikan terhadap nilai perusahaan. Penelitian ini sejalan dengan Yulipratama dan 
Mardani (2017) bahwa peluang pertumbuhan (growth) berpengaruh positif tidak signifikan terhadap nilai perusahaan. Peningkatan pertumbuhan asset (growth) tidak secara langsung berdampak pada peningkatan nilai perusahaan. Peningkatan pertumbuhan asset yang tidak diimbangi dengan peningkatan laba tidak berdampak terhadap nilai perusahaan yang terindeks kompas 100 .

Return on equity (ROE) perusahaan yang masuk dalam indeks kompas 100 di Bura Efek Indonesia mempunyai pengaruh positif terhadap nilai perusahaan dengan koefisien regresi sebesar 0,064. Hasil pengujian menunjukkan bahwa hipotesis $6\left(\mathrm{H}_{6}\right)$ terbukti signifikan, hal ini dapat ditunjukkan dengan nilai t hitung sebesar 9,565 yang lebih dari t tabel $(1,96)$ serta nilai probabilitas $(0,000)<\alpha(0,05)$. Hasil penelitian sejalan dengan Mahendra (2012) bahwa profitabilitas (return on equity) berpengaruh positif signifikan terhadap nilai perusahaan. Lebih lanjut Wahyuni dkk (2013) menjelaskan bahwa kemampuan perusahaan dalam menghasilkan laba dibandingkan dengan modal sendiri akan berdampak pada nilai perusahaan (price to book value) pada perusahaan yang terindeks kompas 100 di Bursa Efek Indonesia.

Debt to equity ratio (DER) perusahaan yang masuk dalam indeks kompas 100 di Bura Efek Indonesia mempunyai pengaruh positif terhadap nilai perusahaan dengan koefisien regresi sebesar 0,124. Hasil pengujian menunjukkan bahwa hipotesis $7\left(\mathrm{H}_{7}\right)$ terbukti signifikan, hal ini dapat ditunjukkan dengan nilai t hitung sebesar 2,802 yang lebih dari $t$ tabel $(1,96)$ serta nilai probabilitas $(0,005)<\alpha(0,05)$. Hasil penelitian sejalan dengan Hermuningsih (2013) bahwa struktur modal (debt to equity ratio) berpengaruh positif signifikan terhadap nilai perusahaan. Lebih lanjut Kosimpang dkk (2017) menjelaskan bahwa struktur modal dengan membandingkan hutang dengan modal sendiri akan berdampak pada nilai perusahaan (price to book value) pada perusahaan yang terindeks kompas 100 di Bursa Efek Indonesia

\section{Koefisien Determinasi}

Besar variasi variabel struktur modal (DER) yang masuk dalam indeks kompas 100 di Indonesia yang dapat diterangkan oleh variasi variabel ukuran perusahaan current ratio $(C R)$, peluang pertumbuhan asset dan return on equity $(R O E)$ adalah sebesar $3,5 \%$, sedangkan sisanya sebesar 96,5\% dipengaruhi oleh variabel lain di luar model penelitian.

Analisis Faktor Yang Mempengaruhi Nilai Perusahaan Go Public

Yang Masuk Dalam Indeks Kompas 100 Dengan Struktur Modal Sebagai Variabel Intervening

(Astohar, Dhian Andanarini Minar Savitri) 
Untuk variabel nilai perusahaan (ROA) yang masuk dalam indeks kompas 100 di Indonesia yang dapat diterangkan oleh variasi variabel current ratio $(C R)$, peluang pertumbuhan asset, return on equity (ROE), dan debt to equity ratio (DER) adalah sebesar $22,2 \%$, sedangkan sisanya sebesar 77,8 \% dipengaruhi oleh variabel lain di luar model penelitian.

\section{Sobel Test}

Hasil sobel test menunjukkan bahwa variabel intervening (debt to equity ratio) yang merupakan proksi dari struktur modal adalah tidak terbukti. Hal ini dibuktikan dengan nilai t sobel yang masih dibawah $(1,96)$ atau sig diatas 0,05 . Ini menunjukkan bahwa debt to equity ratio tidak dapat terbukti sebagai variabel intervening atau memdiasi pengaruh dari likuiditas (current ratio), peluang pertumbuhan asset (growth) dan profitabilitas (return on equity) terhadap nilai perusahaan (price to book value).

\section{PENUTUP}

\section{Implikasi Manajerial}

1. Perlu memperhatikan kemampuan membayar dari perusahaan secara jangka pendek maupun jangka panjang dengan melihat kondisi modal sendiri. Penggunaan hutang dikondisi pada posisi yang optimal agar hemat dapat dihemat. Kondisi hutang yang maksimal dapat membuat kondisi keuangan perusahaan dalam kondisi yang kurang aman.

2. Melakukan perimbangan dalam pengelolaan asset untuk pengaturan yang lebih baik dan tepat. Aktiva dimanfaatkan dengan secara tepat sasaran melalui perencanaan dan pengendalian yang terukur.

3. Pembayaran - pembayaran kewajiban atau hutang yang jatuh tempo dalam jangka pendek benar - benar terjadwal dengan baik. Mendahulukan hutang - hutang jangka pendek atau yang jatuh tempo agar likuiditas selalu terjaga dengan tetap focus pada efisiensi dalam pengelolaan modal kerja.

\section{Agenda Mendatang}

1. Variable - variable lainnya seperti struktur modal yang lain (debt to total asset) atau variable - variable rasio aktivitas dapat ditambahkan untuk memperbaiki model penelitian.

2. Obyek penelitian yang ada dapat diperluas lagi atau mengembangkan dengan analisis komparatif dengan sector - sector atau indeks yang lainnya. 
3. Tahun atau peride penelitian dikembangkan lagi menjadi 10 tahun (lebih dari 5 tahun) agar hasil penelitian dapat merepresentasikan populasinya.

ACKNOWLEDGMENTS : Penelitian ini didukung dan dibiaya sepenuhnya oleh Penelitian Dosen Pemula Kementrian Riset, Teknologi dan Pendidikan Tinggi (RISTEKDIKTI) Republik Indonesia 2018

\section{DAFTAR PUSTAKA}

Aditya, Muhamad Angga Eka., 2015., Pengaruh Rasio Keuangan terhadap Nilai Perusahaan Manufaktur Yang Terdaftar di Bursa Efek Indonesia., Jurnal Ilmiah STIE Perbanas., Sekolah Tinggi Ilmu Ekonomi Perbanas Surabaya

Anggraini. Ratih., 2015., Analisis Pengaruh Price Earning Ratio (Per). Debt To Equity Ratio (Der). Return On Asset (ROA). Current Ratio (CR) dan Firmsize Terhadap Nilai Perusahaan (PBV) pada Perusahaan Sektor Property. Real Estate \& Building Construction Yang Terdaftar di Bursa Efek Indonesia (BEI) Tahun 2008-2012., Jurusan Manajemen Fakultas Ekonomi dan Bisnis., Universitas Dian Nuswantoro Semarang

Apsari. Idha Ayu., Dwiatmanto dan Devi Farah Azizah., 2015., Pengaruh Return On Equity. Net Profit Margin. Debt To Equity Ratio. dan Longterm Debt To Equity Ratio terhadap Price Book Value (Studi Pada Perusahaan Sub Sektor Makanan dan Minuman yang Terdaftar di Bursa Efek Indonesia Periode Tahun 2010-2013)., Jurnal Administrasi Bisnis (JAB)|Vol. 27 No. 2 Oktober 2015

Astohar, 2017., Pengaruh Ukuran Perusahaan dan Profitabilitas terhadap Nilai Perusahaan dengan Struktur Modal Sebagai Variabel Intervening (Studi pada Perusahaan Automotive and Allied Products di Bursa Efek Indonesia periode tahun 2010 - 2015)., Among Makarti., Vol 10 No 20, Desember 2017.

Ayu, Dea Putrid an Suarjaya, A. A. Gede Suarjaya., 2017., Pengaruh Profitabilitas terhadap Nilai Perusahaan dengan Corporate Social Responsibility sebagai Variabel Mediasi pada Perusahaan Pertambangan., E-Jurnal Manajemen Unud, Vol.6, No 2.

Aziz, Hilman Abdul, 2016, “ Pengaruh Proitabilitas Dan Tingkat Pertumbuhan Penjualan Terhadap Nilai Perusahaan Dengan Struktur Modal Sebagai Variabel Intervening Pada Perusahaan Manufaktur Yang Terdaftar Di BEI Periode 2014-2014, Universitas Muhammadiyah Yogyakarta

Brigham. Huston., 2011., Dasar - Dasar Manajemen Keuangan., (Buku 1)., Salemba Empat., Edisi 11 Jakarta

Dewi. Ni Kadek Sugiani Merta dan Badjra. Ida Bagus., 2013., Pengaruh Likuiditas. Profitabilitas. Tangibility Assets. Ukuran Perusahaan dan Pajak Terhadap Struktur Modal., Fakultas Ekonomi., Universitas Udayana., Bali.

Dewi, Dewa Ayu Intan Yoga Maha dan Sudiartha, Gede Mertha., 2016., Pengaruh Profitabilitas, Ukuran Perusahaan, dan Pertumbuhan Aset terhadap Struktur Modal dan Nilai Perusahaan., E-Jurnal Manajemen Unud, Vol. 6, No. 4, 2017: 2222-2252

Ernawati, Dewi, 2016, "Pengaruh Profitabilitas, Leverage Dan Ukuran Perusahaan Terhadap Nilai Perusahaan." Jurnal Ilmu \& Riset Akuntansi 4.4

Fadli, Achmad Agus Yasin, Chabachib, M dan Haryanto, Mulyo., 2013 Analisis Pengaruh Debt To Equity Ratio, Return On Asset, dan Current Ratio Terhadap

Analisis Faktor Yang Mempengaruhi Nilai Perusahaan Go Public

Yang Masuk Dalam Indeks Kompas 100 Dengan Struktur Modal Sebagai Variabel Intervening

(Astohar, Dhian Andanarini Minar Savitri) 
Dividend Payout Ratio Dan Dampaknya Pada Nilai Perusahaan (Studi pada Industri Manufaktur di Bursa Efek Indonesia Periode Tahun 2010-2012)., Jurnal Bisnis Strategi., Vol 22 No.2

Firnanda, Taurisina dan Oetomo, Heni Widi., 2016., Analisis Likuiditas, Profitabilitas, Solvabilitas dan Perputara Persediaan terhadap Nilai Perusahaan., Jurnal Ilmu dan Riset Manajemen., Vol 5 nomor 2, Feb 2016

Ghozali. Imam., 2013., Aplikas Analisis Multivariate dengan Program IBM SPSS 21

Update PLS Regresi., Badan Penerbit Universitas Diponegoro., Semarang.

Herawati, Titin, 2013, "Pengaruh Kebijakan Dividen, Kebijakan Hutang dan Profitabilitas Terhadap Nilai Perusahaan." Jurnal Manajemen, 2.02

Hamidy. Rahman Rusdi., Wiksuana, I Gusti Bagus dan Artini, Luh Gede Sri., 2015., Pengaruh Struktur Modal Terhadap Nilai Perusahaan Dengan Profitabilitas Sebagai Variabel Intervening Pada Perusahaan Properti Dan Real Estate Di Bursa Efek Indonesia., E-Jurnal Ekonomi dan Bisnis Universitas Udayana 4.10 (2015)

Hardanti. Siti dan Gunawan. Barbara., 2010., Pengaruh Size. Likuiditas. Profitabilitas.

Risiko. Dan Pertumbuhan Penjualan terhadap Struktur Modal (Studi Empiris Pada Perusahaan Manufaktur di Bursa Efek Indonesia)., Jurnal Akuntansi dan Investasi Vol. 11 No. 2. halaman: 148-165. Juli 2010

Hartanti. Puji., 2014., Analisis Rasio Likuiditas. Rasio Leverage dan Rasio Profitabilitas Terhadap Price To Book Value (Studi kasus pada perusahaan Food and Beverage yang terdaftar di Bursa Efek Indonesia tahun 2008-2012)., Fakultas EKonomi., Universitas Muhamadyah., Surakarta

Hasania, Zuhria, Murnim Sri, Mandagie, Yunita., 2016., Pengaruh Current Ratio, Ukuran Perusahaan Struktur Modal, dan ROE terhadap Nilai Perusahaan Farmasi yang Terdaftar di Bursa Efek Indonesia Periode 2011 - 2014., Jurnal Berkala Ilmiah Efisiensi, Volume 16 No. 03 Tahun 2016

Hermuningsih. Sri., 2012., Pengaruh Profitabilitas. Size terhadap Nilai Perusahaan dengan Sruktur Modal Sebagai Variabel Intervening., Jurnal Siasat Bisnis., Vol 16 No 2., Juli 2012

Hermuningsih. Sri., 2013., Pengaruh Profitabilitas. Growth Opportunity. Sruktur Modal terhadap Nilai Perusahaan pada Perusahaan Publik di Indonesia., Buletin Ekonomi Moneter dan Perbankan. Oktober 2013

Jariah, Ainun., 2016., Likuiditas, Leverage, Profitabilitas Pengaruhnya terhadap Nilai Perusahaan Manufaktur di Indonesia melalui Kebijakan Deviden., Riset Akuntansi dan Keuangan Indonesia., Vol 1 (2) 2016

Kristian. Nantyo dan Khuzain., 2014., Pengaruh Likuiditas dan Profitabilitas Terhadap Struktur Modal dan Rasio Aktivitas Sebagai Intervening., Jurnal Ilmu \& Riset Manajemen., Vol. 3 No. 12 (2014)

Kartini dan Tulus Arianto. 2008. Struktur Kepemilikan. Profitabilitas. Pertumbuhan Aktiva dan Ukuran Perusahaan terhadap Struktur Modal pada Perusahaan Manufaktur., Jurnal Keuangan dan Perbankan. Vol. 12 No. 1 : 11-21.

Kosimpang, Anung Dian., Andini, Rita dan Oemar, Abrar., 2017., Pengaruh Profitabilitas, Ukuran Perusahaan terhadap Nilai Perusahaan dengan Variabel Struktur Modal Sebagai Variabel Intervening pada Perusahaan Pertambangan yang Terdaftar di BEI Periode Tahun 2012 - 2016., Jurnal Upand., Semarang.

Mahendra. Alfredo Dj., Luh Gede Sri Artini., Suarjaya. A.A Gede., 2012., Pengaruh Kinerja Keuangan Terhadap Nilai Perusahaan pada Perusahaan Manufaktur di 
Bursa Efek Indonesia., Jurnal Manajemen. Strategi Bisnis. dan Kewirausahaan Vol. 6. 131 No. 2 Agustus 2012., Universitas Udayana. Bali.

Mai. Muhammad Umar., 2006. Analisis Variabel-Variabel yang Mempengaruhi Struktur Modal Pada Perusahaan-Perusahaan LQ-45 di Bursa Efek Jakarta. Ekonomika. Politeknik Negeri. Bandung.

Mardiyati, Umi, Gatot Nazir Ahmad, dan Ria Putri. 2012, "Pengaruh Kebijakan Dividen, Kebijakan Hutang Dan Profitabilitas Terhadap Nilai Perusahaan Manufaktur Yang Terdaftar Di Bursa Efek Indonesia (Bei) Periode." Jurnal Riset Manajemen Sains Indonesia (JRMSI), Vol 3 no 1

Martikarini. Nani., 2014., Pengaruh Profitabilitas. Kebijakan Hutang. Dan Dividen Terhadap Nilai Perusahaan Manufaktur Yang Terdaftar Di Bursa Efek Indonesia Periode 2009-2011., Fakultas Ekonomi Jurusan Akuntansi., Universitas Gunadarma., Jakarta

Nugroho. Wahyudi Asto., 2012., Pengaruh Profitabilitas. Likuiditas. Dan Leverage Terhadap Nilai Perusahaan (Studi Pada Perusahaan Sektor Manufaktur di Bursa Efek Indonesia Periode 2008-2011)., Program Studi Magister Manajemen., Program Pasca Sarjana Universitas Muhammadiyah., Surakarta

Nofrita. Ria., 2013., Pengaruh Profitabilitas terhadap Nilai Perusahaan dengan Kebijakan Deviden sebagai Variabel Intervening (Studi Empiris pada Perusahaan Manufaktur yang Terdaftar di BEI)., Fakultas Ekonomi Universitas Negeri Padang

Nuswandari, Cahyani., 2013., Determinan Struktur Modal Dalam Perspektif Pecking Order Theory Dan Agency Theory., Dinamika Akuntansi, Keuangan dan Perbankan, Mei 2013, Hal: 92 - 102 Vol. 2, No. 1

Putra, AA Ngurah Dharma Adi dan Lestari, Putu Vivi., 2016., Pengaruh Kebijakan Dividen, Likuiditas, Profitabilitas dan Ukuran Perusahaan terhadap Nilai Perusahaan., e-Jurnal Manajemen Unud, Vol. 5, No.7, 2016: 4044 - 4070 ISSN : 2302-89124044

Riyanto. Bambang., 2010. Dasar - Dasar Pembelanjaan Perusahaan. Edisi 4. Yayasan Penerbit Gajah Mada. Yogyakarta

Safitri, Ufi Kaniasari., 2017., Pengaruh Profitabilitas dan Size terhadap Nilai Perusahaan dengan Struktur Modal Sebagai Variabel Intervening (Studi Empiris pada Perusahaan Manufaktur yang Terdaftar Di Bursa Efek Indonesia Tahun 2011-2014). http://repository.umy.ac.id/handle/123456789/8696

Salempang, Lita Elisabeth, Jullie J. Sondakh, Pusung, Rudy J.., 2016., Pengaruh Return On Asset, Debt to Equity dan Pertumbuhan Penjualan terhadap Nilai Perusahaan pada Sektor Real Estate dan Property yang Terdaftar di BEI Tahun 2013-2014., Jurnal Berkala Ilmiah Efisiensi Volume 16 No. 03 Tahun 2016

Sartono. Agus., 2009., Manajemen Keuangan : Teori dan Aplikasi., (Edisi 4)., BPFE., Yogyakarta

Sujoko dan Subiantoro. 2007. Pengaruh Kepemilikan Saham. Laverage. Faktor Intern dan Faktor Ektern Terhadap Nilai Perusahaan (Studi Emperik Pada Perusahaan Manufaktur di Bursa Efek Jakarta). Jurnal Manajemen dan Kewirausahaan. 9 (1). 41-48.

Analisis Faktor Yang Mempengaruhi Nilai Perusahaan Go Public

Yang Masuk Dalam Indeks Kompas 100 Dengan Struktur Modal Sebagai Variabel Intervening

(Astohar, Dhian Andanarini Minar Savitri) 
Syamsuddin. Lukman. 2011., Manajemen Keuangan Perusahaan (Konsep Aplikasi dalam: Perencanaan. Pengawasan. dan Pengambilan Keputusan) (Edisi Baru)., Rajawali Press., Jakarta

Wahyuni. Tri., Ernawati. Endang., Murhadi. Werner., 2013., Faktor - factor yang Mempengaruhi NIlai Perusahaan di Sektor Property. Real Estate \& Building Construction yang terdaftar di Bei Periode., 2008 - 2012., Calyptra : Jurnal Ilmiah Mahasiswa Universitas Surabaya. VOl 2 no 1 (2013)

Wardani. Mustika., 2015 Analisis Pengaruh Profitabilitas. Likuiditas dan Struktur Aktiva Terhadap Struktur Modal pada Perusahaan Manufaktur yang Terdaftar di BEI Tahun 2011-2013., Program Magister Manajemen., Universitas Muhamadyah Surakarta., Surakarta

Yulipratama, Hendra Bagus dan Mardani, Ronny M., 2017., ANALISIS PENGARUH PROFITABILITAS, LEVERAGE, DAN UKURAN PERUSAHAAN TERHADAP NILAI PERUSAHAAN (Studi Pada Perusahaan Pertambangan Yang Terdaftar Di Bursa Efek Indonesia Tahun 2012-2015),, e - Jurnal Riset Manajemen Prodi Manajemen., Unisma Malang.

Yusrianti. Hasni., 2013., Pengaruh Tingkat Profitabilitas. Struktur Asset. dan Growth Opportunity Terhadap Struktur Modal Pada Perusahaan Manufaktur yang Telah Go Public Di Bursa Efek Indonesia., Laporan Penelitian Dana Fakultas Ekonomi Unsri. Surakarta 